\title{
How Acute and Chronic Alcohol Consumption Modulate Multiple Neurotransmitter Systems: A Review of Clinical PET Neuroimaging
}

Koen Van Laere ${ }^{1,2}$ and Jenny Ceccarini ${ }^{1,2^{*}}$

${ }^{1}$ Department of Imaging and Pathology, Division of Nuclear Medicine \& Molecular Imaging, KU Leuven, 3000 Leuven, Belgium

${ }^{2}$ MoSAIC, Molecular Small Animal Imaging Center, KU Leuven, 3000 Leuven, Belgium

*Corresponding author: Jenny Ceccarini, PhD, Department of Imaging and Pathology, Division of Nuclear Medicine \& Molecular Imaging, Herestraat 49 , 3000 Leuven, Belgium, Tel: +3216343715; Fax: +3216343759; E-mail: jenny.ceccarini@uzleuven.be

Received date: March 05, 2018; Accepted date: March 28, 2018; Published date: April 05, 2018

Copyright: $\odot 2018$ Van Laere $\mathrm{K}$ and Ceccarini J. This is an open-access article distributed under the terms of the Creative Commons Attribution License, which permits unrestricted use, distribution and reproduction in any medium, provided the original author and source are credited.

Keywords: Alcohol; Neuroimaging; Positron Emission Tomography (PET); Addiction; Neurotransmitters

\section{Abbreviations:}

AUD: Alcohol Use Disorder; PET: Positron Emission Tomography; DA: Dopamine; DAT: Dopamine Transporters; GABA: Gammaaminobutyric Acid; EC: Endocannabinoid; NMDA- N-methyl-Daspartate, mGluR5- Metabotropic Glutamate subtype 5 Receptor, $\mathrm{CB}_{1} \mathrm{R}$ : Type 1 Cannabinoid Receptor; MOR: $\mu$-opioid Receptor; NAc: Nucleus Accumbens; PFC: Prefrontal Cortex.

\section{Introduction}

The reinforcing effects of a moderate consumption of alcohol are a consequence of the enhancement or interactions between several neurotransmitter systems, including dopamine (DA), gammaaminobutyric acid (GABA), opioid, serotonin, endocannabinoid, and glutamate signaling [1-5]. Alcohol activates the dopaminergic mesocorticolimbic pathway, by increasing the main inhibitory neurotransmitter, GABA and by inhibiting the major excitatory neurotransmitter, glutamate, particularly at the N-methyl-D-aspartate (NMDA) glutamate receptor. However, chronic excessive alcohol consumption leads to alcohol use disorder (AUD), involving various forms of short- and long-term plasticity and neuroadaptations in brain regions involved in the etiology of addiction that are responsible for reward, inhibitory control, motivation, memory and learning [3].

AUD, according to The Diagnostic and Statistical Manual of Mental Disorders (5th edition, DSM-5) for AUD criteria, reflects a single, continuous disorder, including alcohol abuse and alcohol dependence [6]. AUD is a chronic relapsing brain disease characterized by an impaired ability to stop or control alcohol use despite adverse social, occupational, or health consequences, affecting 15.1 million American adults (according to the Results from the 2015 US National Survey on Drug Use and Health). Recovery from alcohol dependence remains challenging with high rates of relapse ( $80 \%$ within the first year) despite available therapies [7]. Only a minority of social drinkers will ever transit from a controlled drinking pattern to AUD and therefore understanding the factors that underlie the vulnerability to alcohol dependence has become central to alcohol research. Over the last two decades, the currently approved pharmacotherapeutic interventions developed for the treatment of AUD include naltrexone, acamprosate, and disulfiram. Although these drugs reduce severity of withdrawal symptoms during alcohol detoxification, reduce craving and support abstinence [8-11], there are no available drugs that can successfully antagonize the adverse effects of excessive drinking (for a recent review on drug development), see [12].
To improve treatment outcome, understanding the neurobiological mechanisms that mediate successful recovery and identifying suitable biomarkers that may predict vulnerability, relapse and/or guide therapeutic intervention is still a crucial issue in alcohol research.

Neuroimaging holds particular promise in that field because of its capacity to link both molecular processes and in vivo observations. In the last decades, neuroimaging studies have brought major insights into the neural correlates of addiction and how these relate to addictive behaviour [13-15]. In particular positron emission tomography (PET) has been an effective noninvasive imaging technique in vivo that can directly probe molecular underpinning in the brain by its unique ability to visualize and quantify neurochemical processes involved in addiction with high selectivity and specificity. The use of PET to study the effects of acute and chronic alcohol on the human brain has enhanced our understanding of the mechanisms underlying the rewarding effects of alcohol, the neuroadaptations from chronic exposure that contribute to tolerance and withdrawal, and the changes in fronto-striatal-limbic circuits that lead to loss of control and enhanced motivation to drink that characterize AUD. In the last decades, PET imaging has been extensively used to investigate various key components of the DAergic synapse, both presynaptically including DA transporters (DAT) (with $\left[{ }^{11} \mathrm{C}\right] \mathrm{MP}$ or $\left[{ }^{11} \mathrm{C}\right] \mathrm{PE} 2 \mathrm{I}$ as radioligands) and DA synthesis capacity (with $\left[{ }^{18} \mathrm{~F}\right] \mathrm{DOPA}$ ), and postsynaptically including DA D2/3 receptors (with $\left[{ }^{11} \mathrm{C}\right]$ raclopride, $\left[{ }^{18} \mathrm{~F}\right]$ fallypride, or $\left.\left[{ }^{11} \mathrm{C}\right] \mathrm{PHNO}\right)$. Nevertheless, an interplay of different neurotransmitter systems has been implicated in the development and maintenance of alcohol dependence.

In this short narrative review we focus on human PET neuroimaging studies on the effects of acute and chronic alcohol consumption on the most prominent neurotransmitter systems, including DA, GABA, glutamate, endocannabinoid and opioid signaling.

\section{PET and the Acute Effects of Alcohol on Neurotransmitter Systems}

Converging preclinical evidence has shown that acute alcohol administration selectively increases DA release in the shell of the nucleus accumbens (NAc) [16,17]. Thus far, alcohol-induced changes in DA levels and their link to rewarding responses have been investigated in humans almost exclusively with the DA D2/3 receptor antagonist $\left[{ }^{11} \mathrm{C}\right]$ raclopride, allowing striatal areas assessment only, and yielded inconsistent findings [18-22]. For example, Aalto et al. reported a significant reduction in $\left[{ }^{11} \mathrm{C}\right]$ raclopride binding potential in the ventral striatum/NAc after an intravenous alcohol administration [18] 
Citation: Van Laere K, Ceccarini J (2018) How Acute and Chronic Alcohol Consumption Modulate Multiple Neurotransmitter Systems: A Review of Clinical PET Neuroimaging. J Alcohol Drug Depend 6: 307. doi:10.4172/2329-6488.1000307

Page 2 of 6

(Figure 1A), whereas Yoder et al. did not find any DA increases among social drinkers [21].

Likewise, a recent PET study using $\left[{ }^{11} \mathrm{C}\right]-(+)-$ PHNO, a novel DA D3 receptor-preferring radioligand, did not find any striatal DA release upon alcohol administration in social drinkers [23]. These inconsistencies are likely to reflect differences in both alcohol route of administration, type of radioligand, in approaches to quantification and differences in histories of alcohol consumption among subjects. Recently, using the high-affinity DA D2/3 receptor ligand $\left[{ }^{18} \mathrm{~F}\right]$ fallypride, a couple of clinical studies explored the effects of acute alcohol on DA levels in extrastriatal brain regions, such as the prefrontal cortex (PFC) [24,25]. In the study performed by LeurquinSterk et al., alcohol induced significant $\left[{ }^{18} \mathrm{~F}\right]$ fallypride displacement (hence DA release) in the PFC, temporal and parietal cortices, and thalamus (Figure 1B), and DA release in the anterior cingulate cortex and orbitofrontal and ventromedial PFCs were correlated with subjective 'liking' and 'wanting' effects [24].

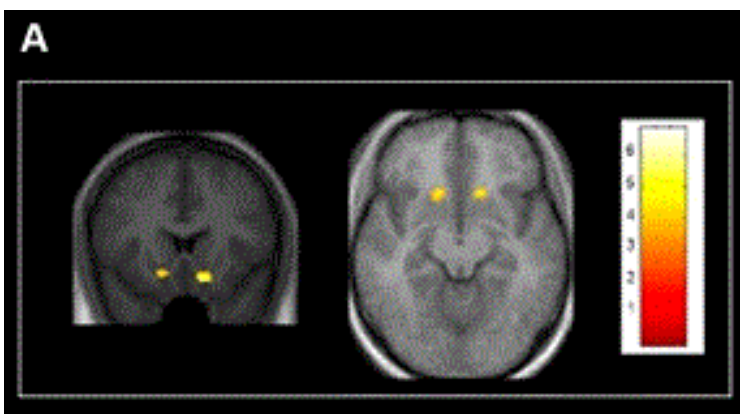

\section{B}

Figure 1: A) Parametric map of $\mathrm{T}$ value of the analysis testing the decrease in $\left[{ }^{11} \mathrm{C}\right]$ raclopride binding potential during alcohol intervention in comparison to the baseline (Figure adapted from Aalto et al.). B) Average parametric t map showing alcohol-induced DA release using $\left[{ }^{18} \mathrm{~F}\right]$ fallypride in relation to subjective "wanting" effects (Figure adapted from [24]).

Besides the dopaminergic signaling, the reinforcing effects of alcohol are in part mediated by endogenous opioids interacting with the $\mu$-opioid receptor (MOR) agonist which binds $\beta$-endorphins and enkephalins which, in turn, increases DA in NAc [26]. Preclinical studies suggest that release of endogenous opioids by ethanol act to promote further consumption $[27,28]$. A human $\left[{ }^{11} \mathrm{C}\right]$ carfentanil PET study showed that drinking alcohol significantly increased opioid release in the NAc and orbitofrontal cortex, areas of the brain implicated in reward valuation [29]. Moreover, changes in orbitofrontal cortex $\left[{ }^{11} \mathrm{C}\right]$ carfentanil binding correlated significantly with the subjective high in heavy drinkers [29].

The type 1 cannabinoid receptor $\left(\mathrm{CB}_{1} \mathrm{R}\right)$ and its endogenous agonists also play an important role in the pharmacological action of alcohol [30,31]. A $\left[{ }^{18} \mathrm{~F}\right] \mathrm{MK}-9470$ PET study found that controlled acute alcohol administration resulted in a significant increased $C_{1} R$ availability in healthy social drinkers (Figure $2 \mathrm{~A}$ ), which was modulated by routine alcohol consumption (Figure 2B) [31].

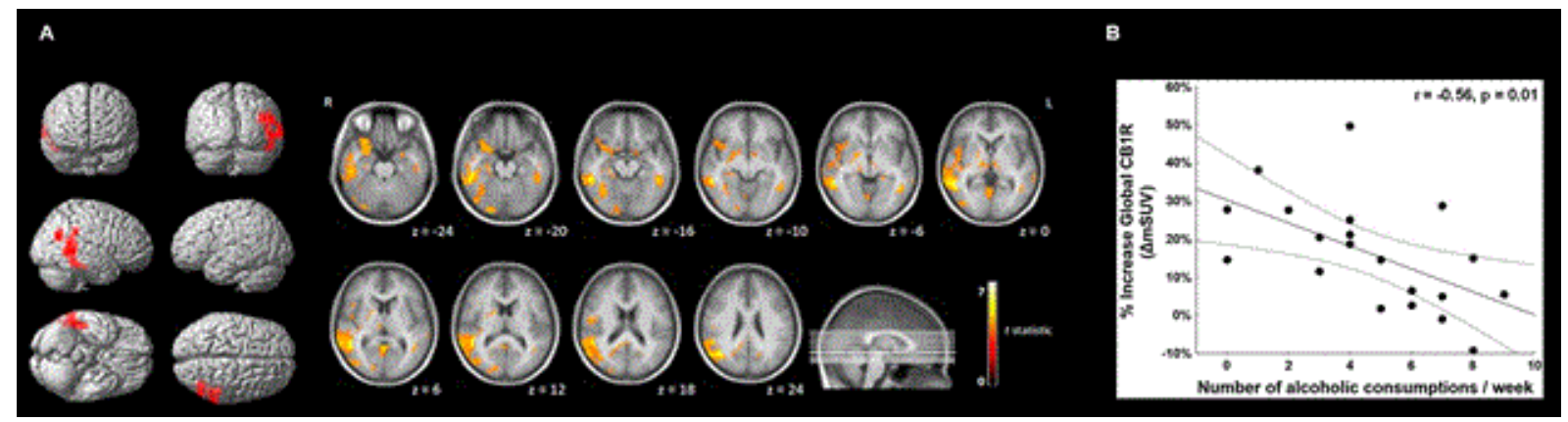

Figure $2:$ A) Statistical parametric mapping results showing increased $\mathrm{CB}_{1} \mathrm{R}$ availability after acute alcohol in social drinkers compared with the baseline condition. B) Negative correlation between the percentage change of the global $\mathrm{CB}_{1} \mathrm{R}$ availability between alcohol and baseline condition in relation to the number of alcoholic consumptions per week. (Figure adapted from [32]).

\section{PET and the Chronic Effects of Alcohol on Neurotransmitter Systems}

Although preclinical models of AUD reveal neuroadaptation in multiple neurotransmitter systems, nowadays the majority of the PET neuroimaging studies investigating neurotransmitter changes in AUD has been focused on the DAergic system [14]. An overview of hypothesized longitudinal changes at the GABA, glutamate, and DA receptor system function during alcohol dependence and withdrawal has been summarized in detail in other reviews $[2,3,33]$.

Overall, PET studies found downregulated DAT during early alcohol withdrawal [34], but with prolonged withdrawal, there were no differences in DATs between alcohol-dependent patients and controls 
[35-37]. Meanwhile, elevated striatal DAT availability in non-smoking alcohol-dependent participants was observed compared to both healthy controls and smoking alcohol-dependent participants at 1 to 5 days abstinence, further highlighting an influence of comorbid tobacco smoking on DA function during alcohol withdrawal [38].

PET studies measuring DA synthesis capacity with the PET radioligand $\left[{ }^{18} \mathrm{~F}\right] \mathrm{DOPA}$ in detoxified alcoholics have reported inconsistent findings [39-41], mainly due in part to small sample sizes limiting the power to identify relevant differences among alcoholics and controls. On the other hand, there is a vast body of literature reporting a consistent reduction in striatal DA D2/3 receptor availability in alcoholics [39,42-46], compared to controls (Figure 3). This reduction in DA D2/3 receptor availability has also been found in extrastriatal regions such as thalamus, hippocampus, and insular and temporal cortex in recently abstinent alcohol-dependent patients $[47,48]$.

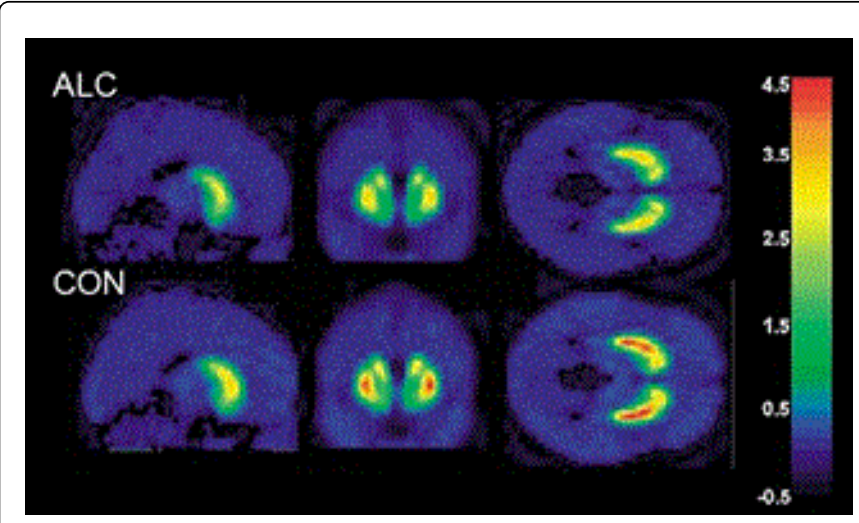

Figure 3 : Comparison of baseline mean V3' maps (calculates as activity (voxel) / mean activity (cerebellum)-1) within alcoholdependent patients (ALC) (top row) and control subjects (CON) (bottom row), as a quantification of DA D2/3 receptor availability. (Figure adapted from [44]).

Until now, only two longitudinal PET DA studies evaluated the effects of detoxification on the recovery of striatal D2/D3R. Volkow et al. showed persistent reductions in striatal D2/3 receptors after 4 months of abstinence $[49,50]$ while Rominger et al. reported significant D2/3 receptors increases in the subgroup of alcohol-dependent subjects who remained abstinent for 1 year [47]. Further DA PET studies are needed to determine whether DA D2/3 receptor can recover as a function of individual alcohol detoxification trajectories and/or whether it could be predict any type of clinical outcome. Lastly, similarly to cocaine and methamphetamine addiction, alcoholdependent subjects reported a strong blunted DA response to amphetamine in the NAc $[44,46]$. Insofar as DA in the NAc is thought to serve as a behavioral switching device, this deficit in DA release may represent an impaired ability of alcohol-dependent individuals to shift from the compulsive, maladaptive patterns of behavior that are indicative of addiction.

Other PET studies focusing on the effects of alcohol effects on neurotransmitter systems have found that chronic alcohol consumption alters the activities of GABA, the brain's principal inhibitory neurotransmitter. The majority of the PET studies measuring GABA-benzodiazepine receptor availability in AUD using the PET radiotracers $\left[{ }^{11} \mathrm{C}\right]$ flumazenil, $\left[{ }^{123} \mathrm{I}\right]$ iomazenil and $\left[{ }^{11} \mathrm{C}\right]$ Ro154513, have found a reduced signaling through $\mathrm{GABA}_{\mathrm{A}}$ receptors in several cortical regions, cerebellum, thalamus, hippocampus and NAc of alcohol-dependent subjects [51-55].

PET studies investigating the opioid system in AUD have found increased MOR availability in abstinent alcohol-dependent subjects using the MOR ligand $\left[{ }^{11} \mathrm{C}\right]$ carfentanil $[26,39]$. In a recent combined MOR PET and post-mortem brain analysis, a significant interaction of opioid receptor $\mu 1$ OPRM1 genotype, $\left[{ }^{11} \mathrm{C}\right]$ carfentanil binding in the ventral striatum, and relapse risk was found [56].

The EC system has been shown to modulate ethanol-motivated behavior, and it has also been demonstrated that chronic ethanol exposure can have potentially long-lasting effects on the EC system $[30,31]$. In the last decades, several PET radioligands have been developed to visualize the $\mathrm{CB}_{1} \mathrm{R}[57,58]$. Most small-animal studies have indicated that chronic ethanol treatment caused decreased $\mathrm{CB}_{1} \mathrm{R}$ protein expression and $\mathrm{G}$ protein coupling [31,59-63]. Brain PET studies in alcohol-dependent subjects, have reported decreases in $\mathrm{CB}_{1} \mathrm{R}$ binding $[32,64]$, compared to controls, that persists during abstinence for at least one month (Figure 4).

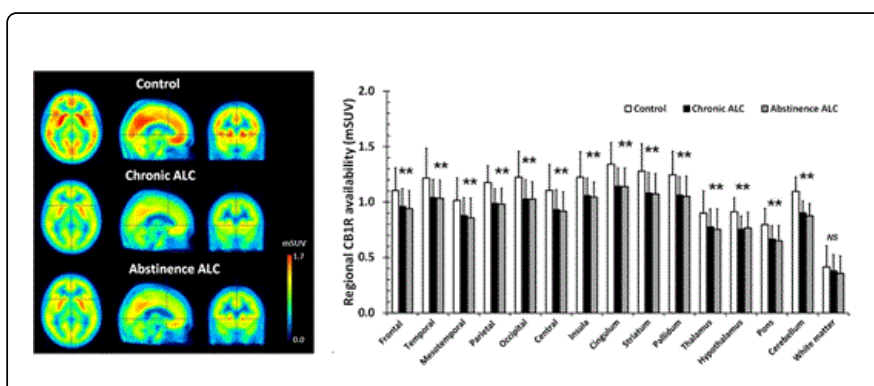

Figure $4: \mathrm{CB}_{1} \mathrm{R}$ decreases in alcoholic patients (ALC) after chronic heavy drinking (Chronic ALC) and abstinence (Abstinence ALC), compared to control condition (Figure adapted from[32]).

According to the glutamate homeostasis hypothesis of addiction proposed by Kalivas $[65,66]$, impaired metabotropic glutamate subtype 5 receptor (mGluR5)-dependent signaling is hypothesized to represent a key component for compulsive drug-seeking that drives AUD. The role of mGluR5 signaling on alcohol addiction has been recently reviewed [67]. In clinical setting, besides regional mGluR5 decreases in both nicotine and cocaine dependent subjects $[68,69]$, mGluR5 PET has recently showed a lower limbic mGluR5 availability in mainly limbic regions of recently abstinent alcohol-dependent subjects [24] (Figure 5). However, after at least a 25-day abstinence, mGluR5 levels have reported a reversible neuroadaptation [70,71].

\section{Future Pathways for PET Neuroimaging in Alcoholism}

PET neuroimaging allows us to visualize and quantify in living human beings what a binge drinking episode might cause to the brain and what damage results from chronic excessive alcohol consumption on different neurotransmitter systems. Currently, PET brain imaging has been mainly focused on changes in DAergic system, and to a lesser extent also the glutamatergic, GABA, opioid and EC system. In summary, consistent long-lasting DAergic and EC signaling changes, a reversible decreased metabotropic glutamatergic receptor system and reduced GABA signaling has been found in alcohol-dependent subjects. However, the full potential of this imaging technique has not yet been realized. Indeed, instead of descriptive pathophysiological 
brain studies, PET could be used to a greater extent if neurotransmitter changes could predict vulnerability and clinical outcome, and they could be used to evaluate proof-of-principle targets or novel pharmacological therapeutics. As an ultimate goal, molecular imaging measures might be used as clinical biomarkers for prognosis, and for supporting and guiding treatment interventions.

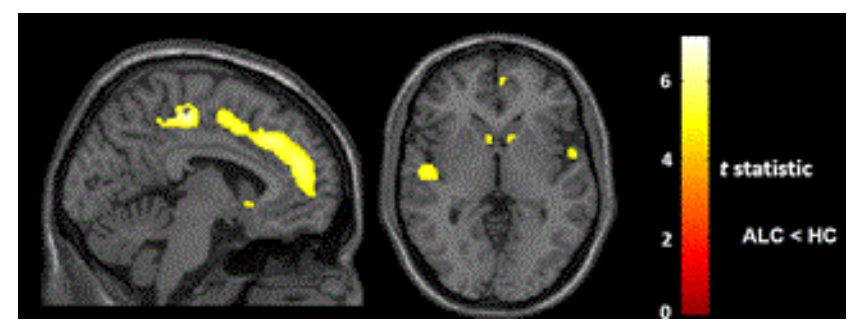

Figure 5: Lower mGluR5 availability ([18F]FPEB $\mathrm{V}_{\mathrm{T}}$ ) in recently abstinent alcohol-dependent subjects (ALC) than in healthy controls (HC). (Figure adapted from [72]).

\section{Acknowledgments}

Jenny Ceccarini is a postdoctoral fellow of the Research Foundation Flanders (FWO), and Prof. Koen Van Laere is a senior clinical research fellow for the FWO and has received an FWO research grant for a part of the cited work (FWO/G.0548.06).

\section{References}

1. Eckardt MJ, File SE, Gessa GL, Grant KA, Guerri C, et al. (1998) Effects of Moderate Alcohol Consumption on the Central Nervous System. Alcoholism, Alcohol Clin Exp Res 22: 998-1040.

2. Koob GF, Volkow ND (2010) Neurocircuitry of Addiction. Neuropsychopharmacology 35: 217-238.

3. Koob GF, Volkow ND (2016) Neurobiology of Addiction: A Neurocircuitry Analysis. Lancet Psychiatry 3: 760-773.

4. Vengeliene V, Bilbao A, Molander A, Spanagel R (2008) Neuropharmacology of Alcohol Addiction. Br J Pharmacol 154: 299-315.

5. Wiers CE, Cabrera E, Skarda E, Volkow ND, Wang GJ (2016) PET Imaging for Addiction Medicine: From Neural Mechanisms to Clinical Considerations. Prog Brain Res 224: 175-201.

6. American Psychiatric Association (2013) Diagnostic and Statistical Manual of Mental Disorders. 5th Ed. Washington, DC: American Psychiatric Association.

7. Weisner C, Matzger H, Kaskutas LA (2003) How Important Is Treatment? One-Year Outcomes of Treated and Untreated Alcohol-Dependent Individuals. Addiction 98: 901-911.

8. Blednov YA, Harris RA (2008) Metabotropic Glutamate Receptor 5 (mGluR5) Regulation of Ethanol Sedation, Dependence and Consumption: Relationship to Acamprosate Actions. Int J Neuropsychopharmacol 11: 775-793.

9. Kalivas PW, Volkow ND (2011) New Medications for Drug Addiction Hiding in Glutamatergic Neuroplasticity. Mol Psychiatry 16: 974-986.

10. Kiefer F, Jahn H, Tarnaske T, Helwig H, Briken P, et al. (2003) Comparing and Combining Naltrexone and Acamprosate in Relapse Prevention of Alcoholism: A Double-Blind, Placebo-Controlled Study. Arch Gen Psychiatry 60: 92-99.

11. Olive MF (2010) Pharmacotherapies for Alcoholism: The Old and the New. CNS Neurol Disord Drug Targets 9: 2-4.

12. Akbar M, Egli M, Cho YE, Song BJ, Noronha A (2017) Medications for Alcohol Use Disorders: An Overview. Pharmacol Ther pii: S0163-7258.
13. Bjork JM, Gilman JM (2014) The Effects of Acute Alcohol Administration on the Human Brain: Insights from Neuroimaging. Neuropharmacology 84: 101-110.

14. Ravan S, Martinez D, Slifstein M, Abi-Dargham A (2014) Molecular Imaging in Alcohol Dependence. Handb Clin Neurol 125: 293-311.

15. Volkow ND, Wiers CE, Shokri-Kojori E, Tomasi D, Wang GJ, et al. (2017) Neurochemical and Metabolic Effects of Acute and Chronic Alcohol in the Human Brain: Studies with Positron Emission Tomography. Neuropharmacology 122: 175-188.

16. Di Chiara G (2002) Nucleus Accumbens Shell and Core Dopamine: Differential Role in Behavior and Addiction. Behav Brain Res 137: 75-114.

17. Howard EC, Schier CJ, Wetzel JS, Duvauchelle CL, Gonzales RA (2008) The Shell of the Nucleus Accumbens Has a Higher Dopamine Response Compared with the Core after Non-Contingent Intravenous Ethanol Administration. Neuroscience 154: 1042-1053.

18. Aalto S, Ingman K, Alakurtti K, Kaasinen V, Virkkala J, et al. (2015) Intravenous Ethanol Increases Dopamine Release in the Ventral Striatum in Humans: PET Study Using Bolus-plus-Infusion Administration of [11C]raclopride. J Cereb Blood Flow Metab 35: 424-431.

19. Boileau I, Assaad JM, Pihl RO, Benkelfat C, Leyton M, et al. (2003) Alcohol Promotes Dopamine Release in the Human Nucleus Accumbens. Synapse 49: 226-231.

20. Urban NB, Kegeles LS, Slifstein M, Xu X, Martinez D, et al. (2010) Sex Differences in Striatal Dopamine Release in Young Adults After Oral Alcohol Challenge: A Positron Emission Tomography Imaging Study With [11C]Raclopride. Biol Psychiatry 68: 689-696.

21. Yoder KK, Albrecht DS, Dzemidzic M, Normandin MD, Federici LM, et al. (2016) Differences in IV Alcohol-Induced Dopamine Release in the Ventral Striatum of Social Drinkers and Nontreatment-Seeking Alcoholics. Drug Alcohol Depend 160: 163-169.

22. Yoder KK, Kareken DA, Seyoum RA, O'connor SJ, Wang C, et al. (2005) Dopamine D2 Receptor Availability Is Associated with Subjective Responses to Alcohol. Alcohol Clin Exp Res 29: 965-970.

23. Thiruchselvam T, Wilson AA, Boileau I, Le Foll B (2017) A Preliminary Investigation of the Effect of Acute Alcohol on Dopamine Transmission as Assessed by [11C]-(+)-PHNO. Alcohol Clin Exp Res 41: 1112-1119.

24. Leurquin-Sterk G, Ceccarini J, Crunelle CL, Weerasekera A, de Laat B, et al. (2017) Cerebral Dopaminergic and Glutamatergic Transmission Relate to Different Subjective Responses of Acute Alcohol Intake: An in Vivo Multimodal Imaging Study. Addict Biol.

25. Pfeifer P, Tüscher O, Buchholz HG, Gründer G, Vernaleken I, et al. (2017) Acute Effect of Intravenously Applied Alcohol in the Human Striatal and Extrastriatal D2/D3 Dopamine System. Addict Biol 22: 1449-1458.

26. Weerts EM, Wand GS, Kuwabara H, Munro CA, Dannals RF, et al. (2011) Positron Emission Tomography Imaging of $\mathrm{Mu}-$ and Delta-Opioid Receptor Binding in Alcohol-Dependent and Healthy Control Subjects. Alcohol Clin Exp Res 35: 2162-2173.

27. Karkhanis A, Holleran KM, Jones SR (2017) Dynorphin/Kappa Opioid Receptor Signaling in Preclinical Models of Alcohol, Drug, and Food Addiction. Int Rev Neurobiol 136: 53-88.

28. Méndez M, Barbosa-Luna IG, Pérez-Luna JM, Cupo A, Oikawa J (2010) Effects of Acute Ethanol Administration on Methionine-enkephalin Expression and Release in Regions of the Rat Brain. Neuropeptides 44: 413-420.

29. Mitchell JM, O'Neil JP, Janabi M, Marks SM, Jagust WJ, et al. (2012) Alcohol Consumption Induces Endogenous Opioid Release in the Human Orbitofrontal Cortex and Nucleus Accumbens. Sci Transl Med 4: $116 \mathrm{ra6}$.

30. Henderson-Redmond AN, Guindon J, Morgan DJ (2016) Roles for the Endocannabinoid System in Ethanol-Motivated Behavior. Prog Neuropsychopharmacol Biol Psychiatry 65: 330-339.

31. Pava MJ, Woodward JJ (2012) A Review of the Interactions between Alcohol and the Endocannabinoid System: Implications for Alcohol Dependence and Future Directions for Research. Alcohol 46: 185-204. 
32. Ceccarini J, Hompes T, Verhaeghen A, Casteels C, Peuskens H, et al (2014) Changes in Cerebral CB1 Receptor Availability after Acute and Chronic Alcohol Abuse and Monitored Abstinence. J Neurosci 34: 2822-2831.

33. Hillmer AT, Mason GF, Fucito LM, O’Malley SS, Cosgrove KP (2015) How Imaging Glutamate, $\gamma$-Aminobutyric Acid, and Dopamine Can Inform the Clinical Treatment of Alcohol Dependence and Withdrawal. Alcohol Clin Exp Res 39: 2268-2282.

34. Laine TP, Ahonen A, Räsänen P, Tiihonen J (1999) Dopamine Transporter Availability and Depressive Symptoms during Alcoho Withdrawal. Psychiatry Res 90: 153-157.

35. Heinz A, Goldman D, Jones DW, Palmour R, Hommer D, et al. (2000) Genotype Influences in Vivo Dopamine Transporter Availability in Human Striatum. Neuropsychopharmacology 22: 133-139.

36. Laine TP, Ahonen A, Torniainen P, Heikkilä J, Pyhtinen J, et al. (1999) Dopamine Transporters Increase in Human Brain after Alcohol Withdrawal. Mol Psychiatry 4: 189-191.

37. Volkow ND, Wang GJ, Fowler JS, Logan J, Hitzemann R, et al. (1996) Decreases in Dopamine Receptors but Not in Dopamine Transporters in Alcoholics. Alcohol Clin Exp Res 20: 1594-1598.

38. Cosgrove KP, Krantzler E, Frohlich EB, Stiklus S, Pittman B, et al. (2009) Dopamine and Serotonin Transporter Availability During Acute Alcohol Withdrawal: Effects of Comorbid Tobacco Smoking. Neuropsychopharmacology 34: 2218-2226.

39. Heinz A, Siessmeier T, Wrase J, Buchholz HG, Gründer G, et al. (2005) Correlation of Alcohol Craving With Striatal Dopamine Synthesis Capacity and D 2/3 Receptor Availability: A Combined $\left[{ }^{18} \mathrm{~F}\right] \mathrm{DOPA}$ and $\left[{ }^{18} \mathrm{~F}\right] \mathrm{DMFP}$ PET Study in Detoxified Alcoholic Patients. Am J Psychiatry 162: $1515-1520$

40. Kumakura Y, Gjedde A, Caprioli D, Kienast T, Beck A, et al. (2013) Increased Turnover of Dopamine in Caudate Nucleus of Detoxified Alcoholic Patients. PLoS ONE 8: e73903.

41. Tiihonen J, Vilkman H, Räsänen P, Ryynänen OP, Hakko H, et al. (1998) Striatal Presynaptic Dopamine Function in Type 1 Alcoholics Measured with Positron Emission Tomography. Mol Psychiatry 3: 156-161.

42. Heinz A, Siessmeier T, Wrase J, Hermann D, Klein S, et al. (2004) Correlation between Dopamine $\mathrm{D}(2)$ Receptors in the Ventral Striatum and Central Processing of Alcohol Cues and Craving. Am J Psychiatry 161: 1783-1789.

43. Hietala J, West C, Syvälahti E, Någren K, Lehikoinen P, et al. (1994) Striatal D2 Dopamine Receptor Binding Characteristics in Vivo in Patients with Alcohol Dependence. Psychopharmacology 116: 285-90.

44. Martínez AT, Speranza M, Ruiz-Dueñas FJ, Ferreira P, Camarero S, et al. (2005) Biodegradation of lignocellulosics: microbial, chemical, and enzymatic aspects of the fungal attack of lignin. Int Microbiol 8: 195-204.

45. Volkow ND, Wang GJ, Fowler JS, Thanos PP, Logan J, et al. (2002) Brain DA D2 Receptors Predict Reinforcing Effects of Stimulants in Humans: Replication Study. Synapse 46: 79-82.

46. Volkow ND, Wang GJ, Telang F, Fowler JS, Logan J, et al. (2007) Profound Decreases in Dopamine Release in Striatum in Detoxified Alcoholics: Possible Orbitofrontal Involvement. J Neurosci 27: 12700-12706.

47. Rominger A, Cumming P, Xiong G, Koller G, Böning G, et al. (2012) $\left[{ }^{18} \mathrm{~F}\right]$ fallypride PET Measurement of Striatal and Extrastriatal Dopamine D2/3 Receptor Availability in Recently Abstinent Alcoholics. Addict Biol 17: 490-503.

48. Spreckelmeyer KN, Paulzen M, Raptis M, Baltus T, Schaffrath S, et al. (2011) Opiate-Induced Dopamine Release Is Modulated by Severity of Alcohol Dependence: An $\left[{ }^{18} \mathrm{~F}\right]$ Fallypride Positron Emission Tomography Study. Biol Psychiatry 70: 770-776.

49. Volkow ND, Wang GJ, Maynard L, Fowler JS, Jayne B, et al. (2002) Effects of Alcohol Detoxification on Dopamine D2 Receptors in Alcoholics: A Preliminary Study. Psychiatry Res 116: 163-172.

50. Volkow ND, Morales M (2015) The Brain on Drugs: From Reward to Addiction. Cell 162: 712-725.
51. Abi-Dargham A1, Krystal JH, Anjilvel S, Scanley BE, Zoghbi S, et al. (1998) Alterations of Benzodiazepine Receptors in Type II Alcoholic Subjects Measured With SPECT and [ $\left.{ }^{123} \mathrm{I}\right]$ Iomazenil. Am J Psychiatry 155: 1550-1555.

52. Lingford-Hughes AR, Acton PD, Gacinovic S, Suckling J, Busatto GF et al. (1998) Reduced Levels of GABA-Benzodiazepine Receptor in Alcohol Dependency in the Absence of Grey Matter Atrophy. Br J Psychiatry 173: 116-122.

53. Lingford-Hughes AR, Wilson SJ, Cunningham VJ, Feeney A, Stevenson B, et al. (2005) GABA-Benzodiazepine Receptor Function in Alcohol Dependence: A Combined 11C-Flumazenil PET and Pharmacodynamic Study. Psychopharmacology 180: 595-606.

54. Lingford-Hughes A, Reid AG, Myers J, Feeney A, Hammers A, et al. (2012) A [ $\left.{ }^{11} \mathrm{C}\right]$ Ro15 4513 PET Study Suggests That Alcohol Dependence in Man Is Associated with Reduced a5 Benzodiazepine Receptors in Limbic Regions. J Psychopharmacol 26: 273-281.

55. Neiman J, Litton JE (2000) Reduced [11C]flumazenil Radioligand Binding in the Thalamus in Alcoholics. Addict Biol 5: 97-99.

56. Hermann D, Hirth N, Reimold M, Batra A, Smolka MN, et al. (2017) Low $\mu$-Opioid Receptor Status in Alcohol Dependence Identified by Combined Positron Emission Tomography and Post-Mortem Brain Analysis. Neuropsychopharmacology 42: 606-614.

57. Ahamed M, Verbruggen A, Bormans G (2013) Synthetic Strategies for Radioligands for in Vivo Imaging of Brain Cannabinoid Type-1 Receptors. J Labelled Comp Radiopharm 56: 207-214.

58. Horti AG, Van Laere K (2008) Development of Radioligands for in Vivo Imaging of Type 1 Cannabinoid Receptors (CB1) in Human Brain. Curr Pharm Des 14: 3363-3383.

59. Basavarajappa BS, Saito M, Cooper TB, Hungund BL (2000) Stimulation of Cannabinoid Receptor Agonist 2-Arachidonylglycerol by Chronic Ethanol and Its Modulation by Specific Neuromodulators in Cerebellar Granule Neurons. Biochim Biophys Acta 1535: 78-86.

60. Basavarajappa BS, Yalamanchili R, Cravatt BF, Cooper TB, Hungund BL (2006) Increased Ethanol Consumption and Preference and Decreased Ethanol Sensitivity in Female FAAH Knockout Mice. Neuropharmacology 50: 834-844.

61. Ceccarini J, Casteels C, Koole M, Bormans G, Van Laere K (2013) Transient Changes in the Endocannabinoid System after Acute and Chronic Ethanol Exposure and Abstinence in the Rat: A Combined PET and Microdialysis Study. Eur J Nucl Med Mol Imaging 40: 1582-1594.

62. Hansson AC, Bermúdez-Silva FJ, Malinen H, Hyytiä P, Sanchez-Vera I, et al. (2007) Genetic Impairment of Frontocortical Endocannabinoid Degradation and High Alcohol Preference. Neuropsychopharmacology凶32: 117-126.

63. Vinod KY, Yalamanchili R, Xie S, Cooper TB, Hungund BL (2006) Effect of Chronic Ethanol Exposure and Its Withdrawal on the Endocannabinoid System. Neurochem Int 49: 619-625.

64. Hirvonen J, Zanotti-Fregonara P, Umhau JC, George DT, Rallis-Frutos D, et al. (2013) Reduced Cannabinoid CB1 Receptor Binding in Alcohol Dependence Measured with Positron Emission Tomography. Mol Psychiatry 18: 916-921

65. Kalivas PW (2009) The Glutamate Homeostasis Hypothesis of Addiction. Nat Rev Neurosci 10: 561-572.

66. Holmes A, Spanagel R, Krystal JH (2013) Glutamatergic Targets for New Alcohol Medications. Psychopharmacology 229: 539-554.

67. Kumar J, Ismail Z, Hatta NH, Baharuddin N, Hapidin H, et al. (2017) Alcohol Addiction- Metabotropic Glutamate Receptor Subtype 5 And Its Ligands: How They All Come Together. Curr Drug Targets 18.

68. Milella MS, Marengo L, Larcher K, Fotros A, Dagher A, et al. (2014) Limbic System mGluR5 Availability in Cocaine Dependent Subjects: A High-Resolution PET [(11)C]ABP688 Study. NeuroImage 98: 195-202.

69. Akkus F, Ametamey SM, Treyer V, Burger C, Johayem A, et al. (2013) Marked Global Reduction in mGluR5 Receptor Binding in Smokers and Ex-Smokers Determined by [11C]ABP688 Positron Emission Tomography. Proc Natl Acad Sci U S A 110: 737-742. 
Citation: Van Laere K, Ceccarini J (2018) How Acute and Chronic Alcohol Consumption Modulate Multiple Neurotransmitter Systems: A Review of Clinical PET Neuroimaging. J Alcohol Drug Depend 6: 307. doi:10.4172/2329-6488.1000307

Page 6 of 6

70. Akkus F, Mihov Y, Treyer V, Ametamey SM, Johayem A, et al. (2018) Metabotropic Glutamate Receptor 5 Binding in Male Patients with Alcohol Use Disorder. Transl Psychiatry 8: 17.

71. Akkus F, Treyer V, Johayem A, Ametamey SM, Mancilla BG, et al. (2016) Association of Long-Term Nicotine Abstinence With Normal Metabotropic Glutamate Receptor-5 Binding. Biol Psychiatry 79: 474-480.
72. Leurquin-Sterk G, Ceccarini J, Crunelle CL, de Laat B, Verbeek J, et al. (2018) Lower Limbic Metabotropic Glutamate Receptor 5 Availability in Alcohol Dependence. J Nucl Med pii: jnumed.117.199422. 